\title{
Shape as a function of time + raw material + burial context? An exploratory analysis of Perdiz arrow points from the ancestral Caddo area of the American Southeast
}

\author{
Robert Z. Selden, Jr. ${ }^{\mathrm{a}, \mathrm{b}, \mathrm{c} *}$, John E. Dockall ${ }^{\mathrm{d}, \mathrm{e}}$, C. Britt Bousman ${ }^{\mathrm{f}, \mathrm{g}, \mathrm{h}}$, and \\ Timothy K. Perttula ${ }^{i}$

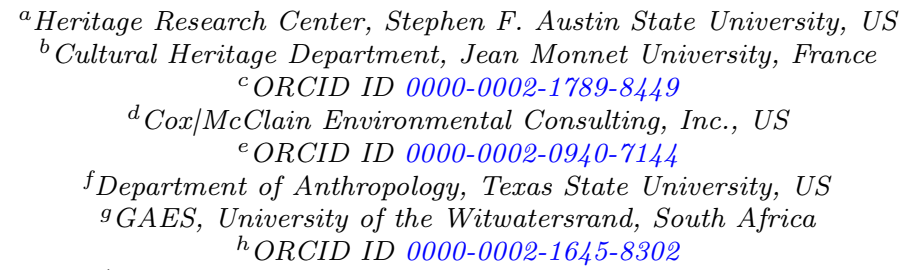

\begin{abstract}
Temporal assignments carry substantive weight, and archaeologists regularly assume that artefacts from discrete temporal units may differ in ways that convey changes in preference or behaviour. Similarly, archaeologists regularly assume that raw material differences articulate with stone tool morphology, and the role of differential raw material quality and preference associated with Caddo lithic technology remains largely unexplored. Whether a particular artefact is found in or outside of burial contexts is a sensitive and regularly discussed topic in the archaeological literature, providing valuable insights related to prehistoric burial practices, as well as generational shifts in aesthetics, design, and raw material preferences. These assumptions were tested using geometric morphometrics, yielding results in support of the hypothesis that Perdiz arrow point shape is protean, and that significant differences existed in shape by time, raw material, and burial context.
\end{abstract}

Keywords: NAGPRA, computational archaeology, digital archaeology, museum studies, digital humanities, STEM, elliptical Fourier analysis

${ }^{*}$ Corresponding author, Robert Z. Selden, Jr. (zselden@sfasu.edu) 
Perdiz arrow points (Suhm \& Jelks, 1962, 283 and Plate 142; Suhm et al., 1954, 504 and Plate 131) are distributed broadly across most of Texas from the Rio Grande eastward to the Neches and Angelina River basins, and from 5 the Red River (Texas and Oklahoma) south to the eastern and central parts of the Gulf Coast (Prewitt, 1995, Figure 40), and have been noted to include more variation in both size and proportion than most arrow point types found in Texas. In outline, Perdiz arrow points possess a:

[t]riangular blade with edges usually quite straight but sometimes slightly convex or concave. Shoulders sometimes at right angles to stem but usually well barbed. Stem contracted, often quite sharp at base, but may be somewhat rounded. Occasionally, specimen may be worked on one face only or mainly on one face... [w]orkmanship generally good, sometimes exceedingly fine with minutely serrated blade edges (Suhm et al., 1954, 504).

This exploratory study assesses whether Perdiz arrow points differ in shape by 1) time as a means of identifying whether abrupt or gradual shape changes occur in Perdiz arrow points through the Middle, Late, and Historic Caddo periods, 2) raw material as a means of identifying whether Perdiz arrow point shape differs if produced using chert, quartzite, or silicified wood, and 3) burial context as a potential means of exploring design intent.

Perdiz arrow points (Figure 1) comprise one aspect of Late Prehistoric bifacial technology that employs flakes or blade-like flakes as blanks in their manufacture. Examples abound across Texas that range from fully bifacial to mostly 25 or partially unifacial on the blade with a bifacial stem. At present, there have been no extensive morphological or technological studies of Perdiz arrow point manufacturing trajectories for northeast Texas. Therefore, the brief synopsis below references cultural resource management (CRM) literature from central 


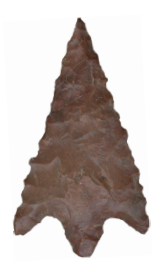

a

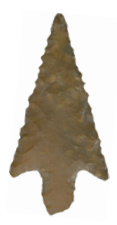

b

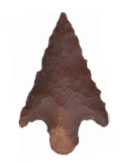

C
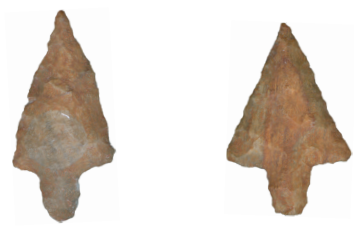

e

Figure 1: Selected Perdiz arrow points from the sample; a, 41CP12 NAGPRA 2012.1.557; b, 41CP5, NAGPRA 2012.1.659; c, 41CP5, NAGPRA 2012.1.646; d, 41NA49, 7; e, 41NA49, 8. All arrow points in this figure are from NAGPRA contexts, and are included here with the permission of the Caddo Nation of Oklahoma.

Texas with understood caveats of its applicability in northeast Texas given the regional raw material differences that exist between central and northeast Texas.

There are two general manufacturing trajectories represented among Perdiz assemblages that reflect differences in blank type: flake versus blade flake (Dockall et al., 2021, I-120-I-121; Johnson, 1994, 66-80; and Ricklis, 1994, 213-214). The first trajectory begins with flake or flake blades of a suitable size and shape.

In this trajectory, the stem is the first component of the arrow point to be manufactured, followed by the barbs and blade edges. The stem is completed using pressure flaking or edge nibbling, leaving much of the lateral edges of the flake unmodified until the stem is completed. The second trajectory involved the selection of appropriate flake blanks. Pressure, percussion, or a mix of these flaking techniques was used to create preforms comparable in shape to bifaces traditionally referenced as Clifton arrow points (Suhm et al., 1954, 496-497). Lateral blade edges, shoulders, barbs and stems appear to have been completed in unison as manufacture proceeded. Stems began as shallow concavities on the lower lateral edges of the proximal end but became deeper and more angular 
until the contracting stem was completed. Refinement of blade edges appears to have proceeded apace with stem finishing.

Perdiz arrow points fall within what Bleed $(1986,738-741)$ referred to as a reliable tool; however, unlike dart points, the morphological attributes of arrow points - generally small and thin - somewhat limit discussions of optimisation related to planned breakage caused by impact (Flenniken, 1985; Flenniken \& Raymond, 1986), providing for differing expressions of maintainability (Ahler $\&$ Geib, 2000). The anticipated exploitation of raw material resources, coupled with the perceived technological advantages of using heat treatment (Flenniken \& Garrison, 1975), may have resulted in longer and larger flakes (and more of them), provided the stone reached the requisite temperature (Bleed \& Meier, 1980). Thermal properties of locally-available raw materials remain ill-understood in the Caddo area, and it is unclear whether Caddo knappers enlisted expedient (Domanski \& Webb, 2007; Gregg \& Grybush, 1976), slow and steady (Mercieca \& Hiscock, 2007), or hybrid approaches to heat treatment.

Inferences regarding human behaviour drawn from stone tool raw material source use patterns are predicated on accurate knowledge of the location of those sources actually used (Ambrose, 2006, 365). Similarly, reduction models rooted in knapping experiments make an assumption that the reduction process is known (Teltser, 1991); however, replication experiments have illustrated that

65 numerous manufacturing strategies could be employed to produce the same products (Clark, 1982; Newcomer, 1971).

Local raw material

As illustrated in Figure 2, east Texas geologic formations are poor in lithic tool stone (Banks, 1990, Figure 2.1). Consequently, the scarce lithic raw materials suitable for the manufacture of Perdiz arrow points would have been carefully conserved by the sedentary aboriginal Caddo populations of east Texas (CE 900 - 1680+). In east Texas, only the Pisgah Ridge chert in the Trinity River basin (McGregor, 1993), Manning Fused Glass (Brown, 1976) in the Manning Formation (part of the Jackson group of Eocene age), and various cherts and quartzites 
in the Catahoula Formation - exposed in the Neches River basin - are in "geological formations that contain in situ rocks suitable for the manufacture of stone tools" (Banks, 1990, 49). However, redeposited ancient stream gravels are relatively widespread throughout the uplands of east Texas (Banks, 1990, 56-57). High quality and knappable cobbles of chert, novaculite, and quartzite are present in the Red River gravels in northeastern Texas (Stoeser et al., 2005), as well as the Bowie gravels of the Red-Sulphur River interfluves (Cliff et al., 1996), which derive from chert-bearing formations in the Ouachita Mountains of southeastern Oklahoma (Figure 2) (Banks, 1990, Figure 1.20).

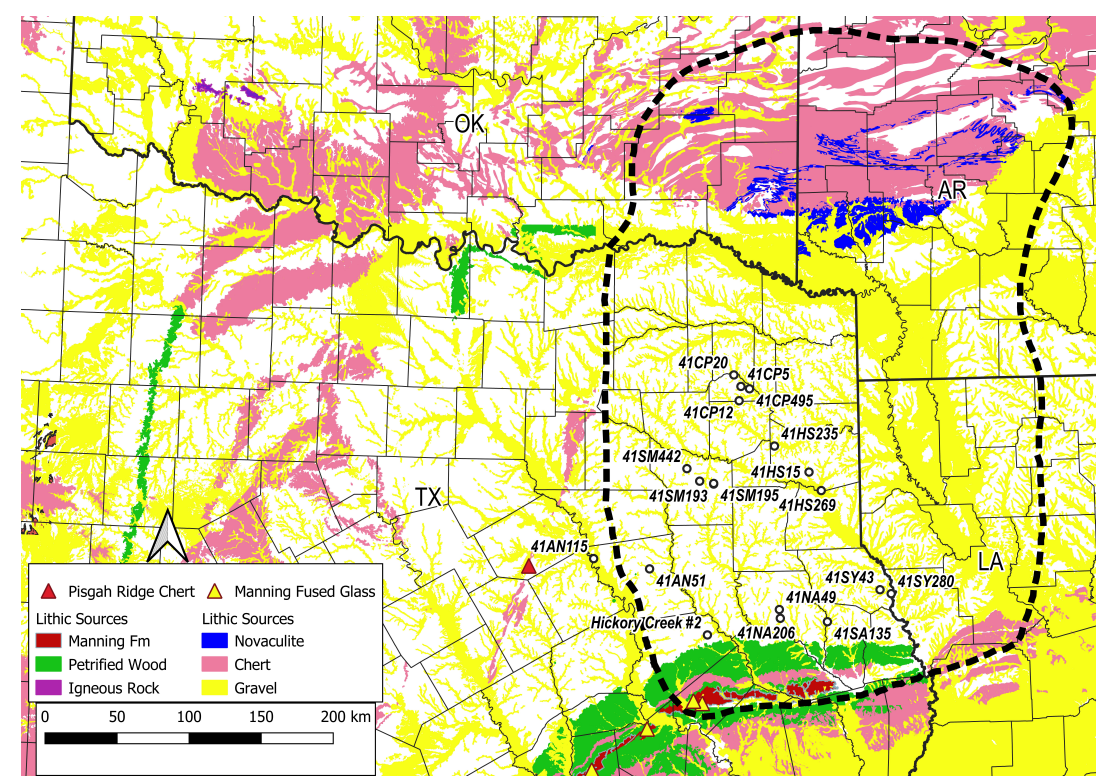

Figure 2: Map of east Texas counties and potential raw material source areas in the Caddo area (black boundary) in Arkansas, Louisiana, Oklahoma, and Texas from the Geologic Map Database of Texas (Stoeser et al., 2005). Pisgah Ridge Chert locale from McGregor (1993) and Manning Fused Glass locales from Brown (1976).

According to a study of lithic raw material sources in the Neches River basin by Girard $(1995,69)$, there are redeposited gravels on stream terraces that contain small cobbles and pebbles of silicified wood, fine-grained quartzite, and various cherts. Local cherts tend to be red, gray, tan, and brown in colour 
(Girard, 1995, 66). Non-local cherts found at sites in the Neches and Angelina river basins are apparently from central Texas Edwards Plateau sources, and are lustrous gray, blue-gray, and dark brown in colour (Girard, 1995).

Local lithic raw materials include coarse- and fine-grained quartzite, silicifed wood, ferruginous sandstone, jasper, and several varieties of earth-toned cherts that are yellowish-brown, gray, red, light brown, brown, greenish-brown, and reddish-brown in colour. Non-local raw materials are white and red novaculite, black chert, dark gray chert, white chert, bluish-gray chert, a yellowish-red chert, and quartz. A distinctive coarse-grained quartzite (or metaquartzite) may occur in this general area, although it may be restricted to localised sources. The material is described by Girard $(1995,67)$ as being of sugary coarse-grained texture and light gray to yellowish-brown in colour, and may originate in the Glover Sandstone (part of the basal Sparta Sand Formation) in northeastern Houston County (see Figure 2) (Girard, 1995, 69). A quarry of grayish-white quartzite is known in the Sabine River basin in Van Zandt County (41VN39), which has been noted to turn pink when heat-treated (Malone, 1972).

The most likely contributing source(s) of non-local cherts used in the manufacture of Perdiz arrow points in northeast and east Texas are those from various Edwards Formation localities in central Texas (Banks, 1990; Perttula, 1984). These resources occur in a region that encompasses the Edwards Plateau and the southern Llano Estacado as both massive ledge and cobble varieties. Raw materials also occur as significant gravel sources along the Colorado and Brazos River valleys (Stoeser et al., 2005), and reworked or lagged members of Uvalde Gravel deposits (Stoutamire \& McBride, 2020). It is likely that Uvalde Gravel deposits extend into east Texas but details are lacking.

\section{Methods and results}

The sample of whole/intact Perdiz arrow points used for this analysis comes from Anderson, Camp, Harrison, Houston, Nacogdoches, San Augustine, Smith, and Shelby counties (Figure 2, supplementary materials [Chapter 5, Table 1], 
and Selden Jr. et al. 2021), and consists of 142 whole/intact Perdiz arrow points from 20 sites across the Caddo area that were manufactured using chert, quartzite, and silicified wood (Figure 3a). Raw material distributions differ among sites, with chert preferred across the broadest geography (Figure 3a). Use of quartzite was limited to Camp, Harrison, and Houston counties, and silicified wood to Houston, Nacogdoches, and Shelby counties; however, Washington Square Mound (41NA49) is the only burial context in the sample where silicified wood Perdiz arrow points have been recovered (Figure 3a).

All three raw material types are present in Caddo burials, (Figure 3b); however, raw materials differ through the Middle, Late, and Historic Caddo periods, where chert, quartzite, and silicified wood are present throughout all three periods, but quartzite only occurs in Middle and Late Caddo contexts (Figure 3c). Radiocarbon and relative dates are discussed in the supplementary materials, and the median of the temporal range was used to assign the Perdiz points to the appropriate temporal period (Middle Caddo, CE 1250-1450; Late Caddo, CE 1450-1680; and Historic Caddo, CE 1680+) (Figure 3d). Information associated with specific sites can be found in Chapter 1 of the supplementary materials, and the full list of samples is included in Table 1 of Chapter 5.

Contingency table analysis

Contingency table analyses of Perdiz arrow points were conducted for raw material and burial context for Middle Caddo, and Late and Historic Caddo period sites are presented below. Chi-square, p values, and Cramer's V were generated using the Real Statistics Resource Pack software add-in for Excel (Charles Zaiontz. www.real-statistics.com. Release 7.2; Copyright 2013-2020). Adjusted residuals were calculated following Haberman (1973), and are significant at a 0.05 level of confidence if greater or equal to 1.96 or less than or equal to -1.96 .

In the Middle Caddo period, Perdiz points manufactured using silicified wood were found in mortuary contexts while those made using chert, quartzite, and silicified wood were found in non-mortuary contexts (Table 1). A chi-square 

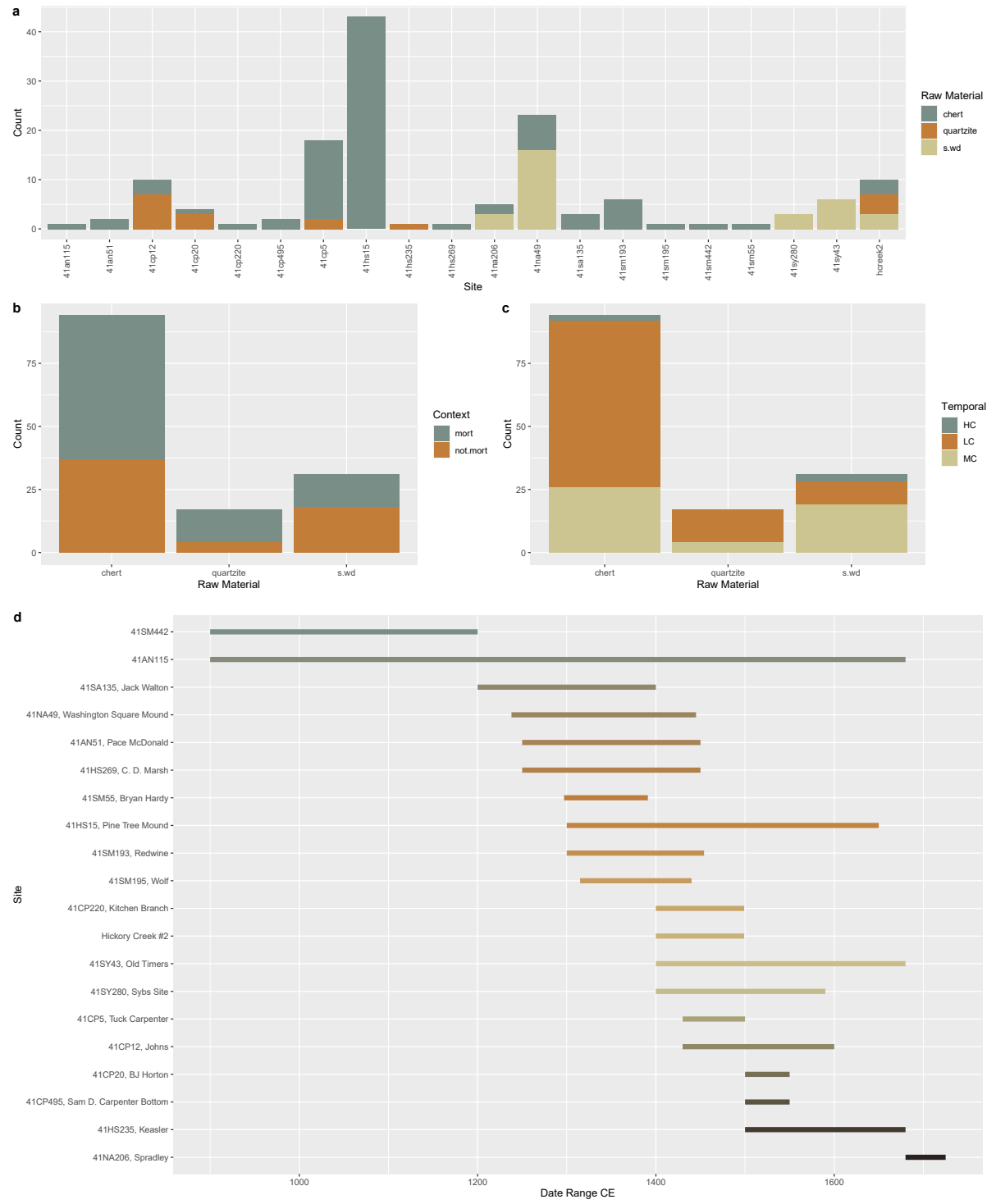

Figure 3: Raw materials a, by site; b, by mortuary context; c, by temporal period (Middle, Late, or Historic Caddo), and d, temporal range of contexts by site in the Perdiz sample. Additional information related to this figure, including the full results and code needed to reproduce it, can be found in the supplemental materials at https://aksel-blaise.github.io/perdiz/rawmaterial.html (Selden Jr. et al., 2021). 
test of independence shows that this pattern is significant, and the Cramer's $\mathrm{V}$ Correlation of 0.755 indicates a moderately strong correlation. Adjusted Residuals indicate that chert and silicified wood are both inversely patterned and the main source of variation (Table 2). Quartzite follows the chert pattern, but does not deviate enough from the expected pattern to be considered significant.

Table 1: Contingency Table for Middle Caddo Perdiz points.*

\begin{tabular}{lccc}
\hline & Mortuary $(\mathrm{O} / \mathrm{E})$ & Non-Mortuary $(\mathrm{O} / \mathrm{E})$ & Total \\
\hline Chert & $0 / 6.9$ & $26 / 19.1$ & 26 \\
Quartzite & $0 / 1.1$ & $4 / 3.0$ & 4 \\
Silicified Wood & $13 / 5.0$ & $1 / 14.0$ & 19 \\
\hline Total & $\mathbf{1 3}$ & $\mathbf{3 6}$ & $\mathbf{4 9}$ \\
\hline${ }^{*} \chi^{2}=27.94, d f=2, p$ value $=8.57^{-7}$, Cramer's $V=0.755$
\end{tabular}

Table 2: Adjusted residuals for Middle Caddo Perdiz points; adjusted residuals are significant at a 0.05 level of confidence if $\geq 1.96$ or $\leq-1.96$. $^{*}$

\begin{tabular}{lcc}
\hline & Mortuary & Non-Mortuary \\
\hline Chert & $\mathbf{- 4 . 4 7}$ & $\mathbf{4 . 4 7}$ \\
Quartzite & -1.26 & 1.24 \\
Silicified Wood & $\mathbf{5 . 2 8}$ & $\mathbf{- 5 . 2 9}$ \\
\hline \multicolumn{2}{r}{${ }^{*} C V \alpha$} & $0.05>1.96$ or $\leq-1.96$
\end{tabular}

The contingency table analysis for Late and Historic Caddo periods was undertaken using the same methodology and software. The Late and Historic Caddo pattern is the inverse of the Middle Caddo pattern (Table 3). In the $4)$. 
Table 3: Contingency table for Late and Historic Caddo Perdiz points.*

\begin{tabular}{lccc}
\hline & Mortuary $(\mathrm{O} / \mathrm{E})$ & Non-Mortuary $(\mathrm{O} / \mathrm{E})$ & Total \\
\hline Chert & $57 / 51.2$ & $11 / 16.8$ & 68 \\
Quartzite & $13 / 9.8$ & $0 / 3.2$ & 13 \\
Silicified Wood & $0 / 9.0$ & $12 / 3.0$ & 12 \\
\hline Total & $\mathbf{7 0}$ & $\mathbf{2 3}$ & $\mathbf{9 3}$
\end{tabular}

$$
\begin{gathered}
{ }^{*} \chi^{2}=\overline{43.47, d f=2, p \text { value }=3.64^{-10}, \text { Cramer's } V=0.684 ; L C \text { and HC are binned }} \\
\text { together here due to sample size, and are culturally connected. }
\end{gathered}
$$

Table 4: Adjusted residuals for Late and Historic Caddo Perdiz points; adjusted residuals are significant at a 0.05 level of confidence if $\geq 1.96$ or $\leq-1.96$. $^{*}$

\begin{tabular}{lcc} 
& Mortuary & Non-Mortuary \\
\hline Chert & $\mathbf{3 . 1 5}$ & $\mathbf{- 3 . 1 5}$ \\
Quartzite & $\mathbf{2 . 2 3}$ & $\mathbf{- 2 . 2 3}$ \\
Silicified Wood & $\mathbf{- 6 . 4 8}$ & $\mathbf{6 . 4 8}$ \\
\hline \multicolumn{2}{c}{${ }^{*} C V \alpha$} & $0.05 \geq 1.96$ or $\leq-1.96$
\end{tabular}

Elliptical Fourier Analysis

Two-dimensional (2D) images of the Perdiz arrow points from the Washington Square Mound site and Turner collection were collected at 600dpi as uncompressed tiff files, and all other images were digitised from figures used in articles and technical reports available through the Index of Texas Archaeology (supplementary materials [Chapter 2]). Images were masked in Adobe Photoshop 2021 (v. 22.1.1), exported as jpegs, then imported to R (Team, 2021), where the Momocs package was used for an elliptical Fourier analysis (EFA) tool shape (Gero \& Mazzullo, 1984; Hoggard et al., 2019; Ioviţă, 2009, 2010, 2011; Ioviţă \& McPherron, 2011; Ioviţă et al., 2017; Ivanovaitè et al., 2019; Saragusti et al., 2005; Serwatka, 2015), and provides visualisations complementary to traditional descriptions, as well as linear and/or orthogonal metrics. The outline of each projectile was retained, and all specimens were normalised to a common centroid, then rescaled using centroid size (Bonhomme et al., 2017).

The calibrate harmonic power function was used to identify the number of harmonics necessary to capture Perdiz point shape (Bonhomme et al., 2014), 
and 11 harmonics were retained to achieve 99 percent harmonic power. An exploratory measure (EFA-PCA) was employed to assess variability among time, raw material, and burial context (supplemental materials [Chapter 5] and Selden Jr. et al. 2021). The shape differences among PC1 occur in blade width, while those for PC2 articulate with stem length (Figure 4, supplemental materials [Chapter 5], and Selden Jr. et al. 2021).

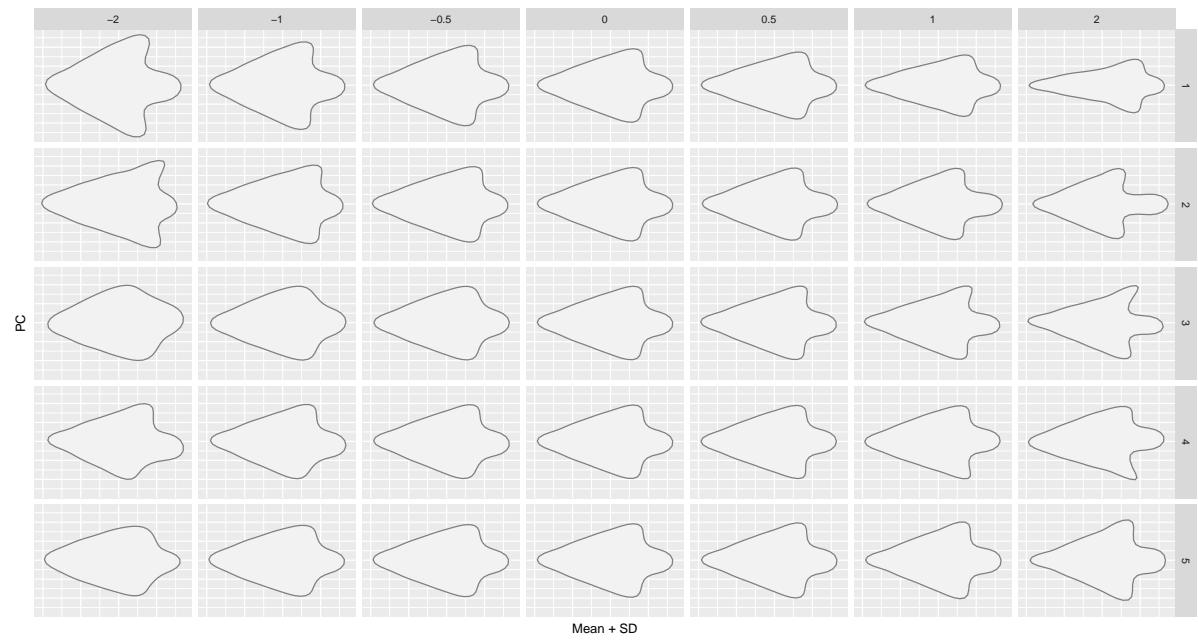

Figure 4: XY tranformations for the first five principal components, comprising 90.7 percent of cumulative shape variation. Additional information related to this figure, including the full results and code needed to reproduce it, can be found in the supplemental materials at https://aksel-blaise.github.io/perdiz/elliptical-fourier-analysis.html and Selden Jr. et al., 2021.

Shape as a function of time

Results of the multivariate analysis of variance (MANOVA) through a HotellingLawley of 99 percent cumulative shape variance indicated a significant difference in Perdiz arrow point shape by time (Hotelling-Lawley: 1.8209, F: 6.1202, $P R(>F): 2.23-16$ ) (Figure 5 [top], supplemental materials [Chapter 5], and Selden Jr. et al., 2021). A subsequent MANOVA with pairwise comparison 
demonstrated a significant difference in mean Perdiz arrow point shape between each of the three temporal periods (Table 5, supplemental materials [Chapter 5], and Selden Jr. et al., 2021). Mean shapes plotted by temporal periods (Middle, Late, and Historic Caddo) indicate a change in Perdiz arrow point shoulder angles through time, ranging from obtuse in the Middle Caddo period, to acute in the Historic Caddo period (Figure 5 [bottom], supplemental materials [Chapter 5], and Selden Jr. et al., 2021). This suggests that a shoulder angle-based metric similar to what Densmore (2007) developed for her analysis of Gary dart points at the Scott site in Oklahoma (34Lf-11) may hold added value for temporally-based research questions related to Perdiz arrow points.

Table 5: Pairwise MANOVA for temporal periods.

\begin{tabular}{|c|c|c|c|}
\hline & Historic & Late & Middle \\
\hline Historic & & $9.561 \mathrm{e}-07$ & $6.203 e-12$ \\
\hline Late & & & $5.950 \mathrm{e}-10$ \\
\hline
\end{tabular}

The marked shift in Perdiz morphology in the Historic Caddo period articulates with the fluorescence of the fur trade, potentially indicating a shape change to a more lethal variant of the Perdiz arrow point. The long narrow stem and tip, acutely pointed and flaring barbs, and overly thin nature of Perdiz arrow points in the Historic Caddo period could represent intentional design choices used to manufacture a projectile point with greater lethal efficiency. The tensile strength of such narrow stems and barbs appear to be functional deficits, particularly if these implements were employed as a hafted cutting tool, or for other similar functions. However, when considered from a perspective of lethality, the design choices make sense, where components may have been designed to fail catastrophically, thus increasing bleeding and/or organ damage. A functional relationship between arrow point design and fracture/fragmentation patterns was suggested by Brown et al. (1982) at 41LK67, and by Black (1986) in his study of Perdiz points from the Clemente and Herminia Hinojosa site (41JW8). 215 Similar fragmentation patterns have been documented by Dockall et al. (2021) 


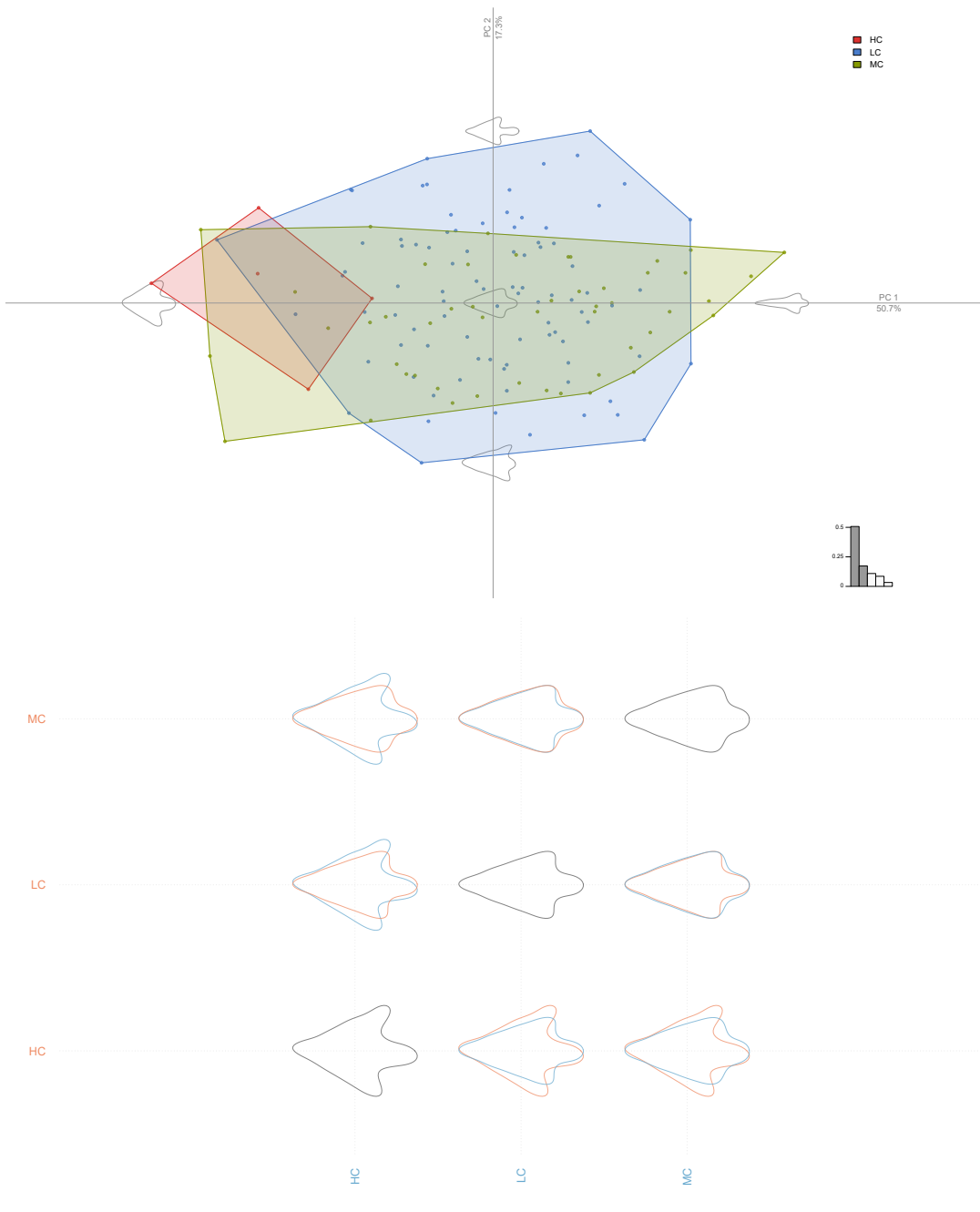

Figure 5: Principal components analysis plot $(\mathrm{PC} 1 / \mathrm{PC} 2)$ for Perdiz arrow points by temporal assignment (top), where green represents projectiles from the Middle Caddo period (CE 1250 - 1450), blue represents projectiles from the Late Caddo period (CE 1450 - 1680), and red represents projectiles from the Historic Caddo period (CE 1680+), as well as comparisons of mean shapes from each period (bottom) where MC, Middle Caddo; LC, Late Caddo; and HC, Historic Caddo. Additional information related to this figure, including the full results and code needed to reproduce it, can be found in the supplemental materials at https://akselblaise.github.io/perdiz/elliptical-fourier-analysis.html and Selden Jr. et al., 2021. 
for Perdiz points from the Jayroe site (41HM51).

The junctions of the stem/body and barb/body represent likely points of failure that - upon impact - would shatter a complete point into several fragments; each with very sharp edges that would further increase haemorrhaging annually for subsistence (LaVere, 1998). Thus, the later shift in Perdiz arrow point morphology may have articulated with a considerable economic need for improved lethal efficiency. By the 1680s, the Caddo fur/hide trade with Europeans was robust, and included bear, beaver, deer, otter, rabbit, raccoon, and 235 others (Carter, 1995; LaVere, 1998; Smith, 1995). When those resources were scarce, Caddo hunters worked in organised groups that would travel a minimum of four days to find buffalo on the plains and prairies (Carter, 1995; Foster, 2008). When trading with the French in Natchitoches, bear's fat would fetch the highest price at 25 livres each, followed by buffalo hides (10 livres/each) and deer skins (35 sous/each) (Carter, 1995).

Shape as a function of raw material

Results of the multivariate analysis of variance (MANOVA) through a HotellingLawley of 99 percent cumulative shape variance indicated a significant difference in Perdiz arrow point shape by raw material (Hotelling-Lawley: 0.77286, F: 
5], and Selden Jr. et al. 2021). A subsequent MANOVA with pairwise comparison demonstrated a significant difference in mean Perdiz arrow point shape for each raw material (Table 6, supplemental materials [Chapter 5], and Selden Jr. et al., 2021). Mean shapes plotted by raw material type (chert, quartzite, and silicified wood) indicate a difference in Perdiz arrow point stem length and bilateral asymmetry, where chert points appear to be the most symmetrical with a longer stem (Figure 6 [bottom], supplemental materials [Chapter 5], and Selden Jr. et al., 2021). Perdiz arrow points manufactured using quartzite appear to be the least symmetrical with the shortest stem; however, Perdiz arrow points manufactured using silicified wood are also asymmetrical, but with a longer stem.

\begin{tabular}{|c|c|c|c|}
\hline & Chert & Quartzite & Silicified Wood \\
\hline Chert & & 0.0050567 & 0.0007521 \\
\hline Quartzite & & & 0.0228460 \\
\hline
\end{tabular}

The documented morphological differences between Perdiz arrow points manufactured using different raw materials can be, at least in part, attributed to the varied geography associated with raw materials (see Figure 2). In the Caddo region, chert, quartzite, and silicified wood all occur as small (less than fist size) cobbles or nodules, often less than $10 \mathrm{~cm}$ in maximum dimension. This mode of raw material occurrence necessitated certain technological innovations to core reduction that allowed knappers to exploit small cobble material. Paramount among these was bipolar percussion and the use of punches and indirect percussion techniques (Dockall et al., 2008; Dockall \& Fields, 2011, 2012; Ensor et al., 1991; Perttula, 1984). These technological options to reduce small cores, produce flake blanks, and shape small hafted bifaces undoubtedly imposed technological and design constraints on Perdiz arrow point manufacture at the local and regional levels that were not factors in the classic Toyah area where raw materials of sufficient size and quality are ubiquitous.

While beyond the scope of this study, it may be possible to accommodate 


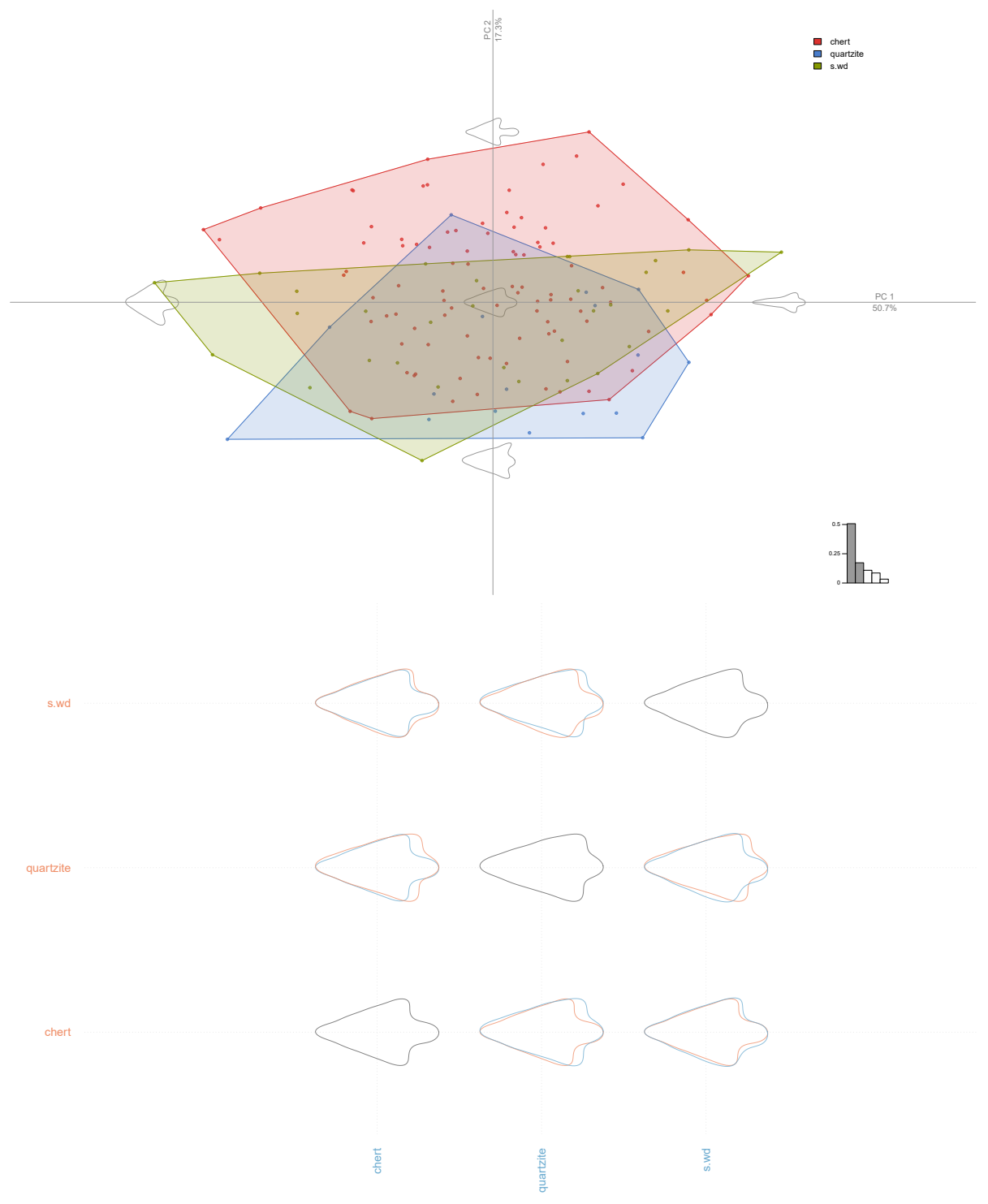

Figure 6: Principal components analysis plot (PC1/PC2) for Perdiz arrow points by raw material (top), where green represents silicified wood, blue represents quartzite, and red represents chert, as well as comparisons of mean shapes from each period (bottom). Additional information related to this figure, including the full results and code needed to reproduce it, can be found in the supplemental materials at https://aksel-blaise.github.io/perdiz/ellipticalfourier-analysis.html and Selden Jr. et al., 2021. 
such design constraints in later studies. The manufacturing trajectory of Perdiz arrow points from the Caddo area has not been the focus of technological lithic studies to date, unlike several central Texas studies that have addressed unique aspects of Perdiz point manufacture choices and their signatures in the archaeological record (Dockall et al., 2021; Ricklis, 1994). Raw material mode of occurrence is an influencing factor on the ultimate morphology and design of tools and is acknowledged as one that is difficult to control for in the analyses, since so little is known of Caddo Perdiz point manufacturing schemes. 


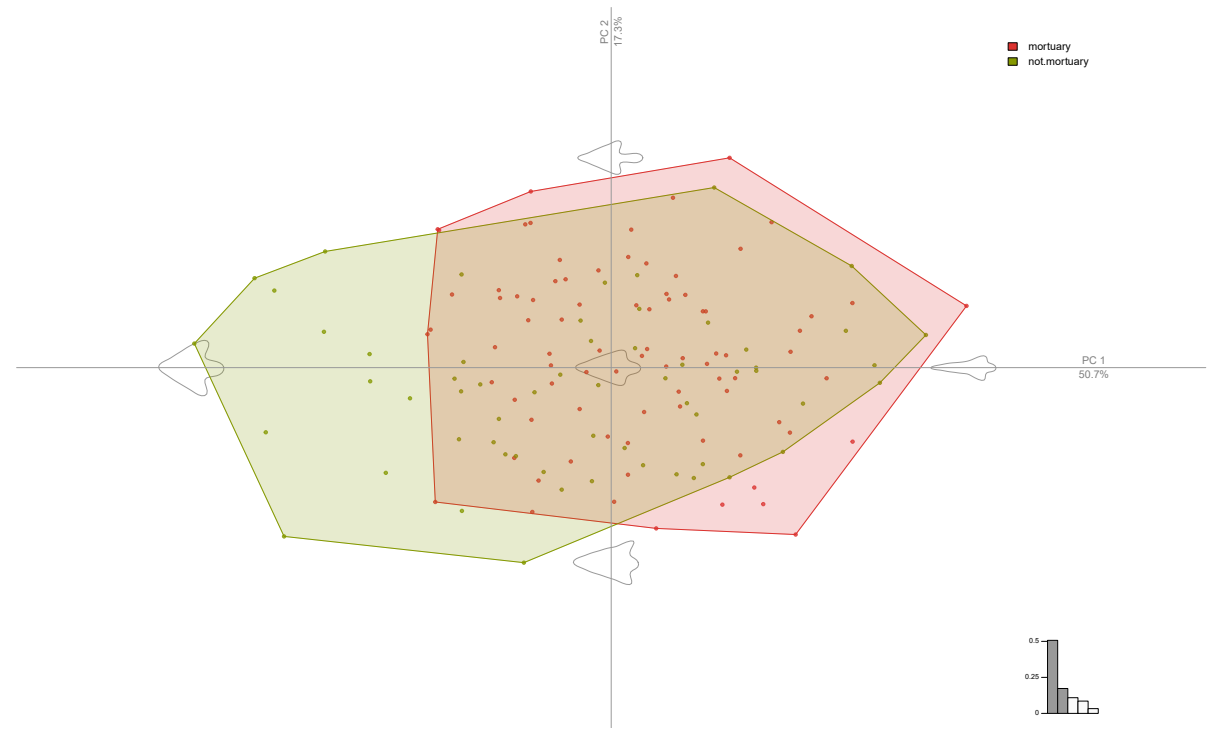

not.mor
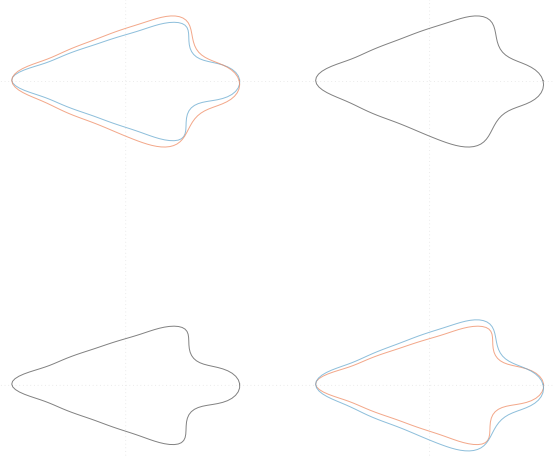

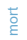

Figure 7: Principal components analysis plot (PC1/PC2) for Perdiz arrow points by mortuary context (in/out) (top), where green represents projectiles not from mortuary contexts, and red represents projectiles from mortuary contexts, as well as comparisons of mean shapes from each context (bottom). Additional information related to this figure, including the full results and code needed to reproduce it, can be found in the supplemental materials at https://akselblaise.github.io/perdiz/elliptical-fourier-analysis.html and Selden Jr. et al., 2021. 


\section{Discussion}

Recent studies of Caddo bottle and biface morphology have revealed a previously unrecognised north-south shape boundary for both bottles and bifaces,

305 and central Texas (Selden Jr., 2018a,b; Selden Jr. et al., 2018; Selden Jr., 2019; Selden Jr. et al., 2020; Selden Jr., 2021b). This exploratory effort expands upon that research programme to include arrow points as a means of analysing shape variability for a third class of artefacts associated with Caddo material culture. The analysis aggregated and analysed the variability in Perdiz arrow point shapes, and resulted in the identification of significant shape differences between temporal components, raw materials, and burial contexts. It confirms that Perdiz arrow point morphology is labile, and that while some of the diagnostic shape differences are distinct, others are more nuanced. It is possible that to Caddo lithic technology (generally) or technological organisation; however, there is a lack of research related to Caddo lithic manufacturing strategies that would be needed to expound upon such questions.

A recent exploratory network analysis used the Historic Caddo ceramic and lithic types recovered from northeast Texas sites - which included Perdiz arrow points - led to the identification of a distinct, and previously unrecognised geographic difference (north-south) in the composition of material culture suites between the Neches and Sabine River basins in northeast Texas (Figure 8) (Selden Jr., 2021a). Results indicated two larger Caddo communities of prac325 tice (Figure 8) (Selden Jr., 2021a, Figure 16.4), in which additional subcommunities of practice were hypothesised to be nested based upon the presence of common suites of material culture types (Selden Jr., 2021a, Figures 16.5 and 16.6). Some of the subcommunities articulate with known Caddo groups, while others do not; however, the networks serve as the requisite foundation for the production of reliable knowledge. Forthcoming morphological analyses will focus upon testing some of those hypotheses; however, additional Perdiz 
arrow points from within the Historic Caddo communities and subcommunities of practice must be integrated into subsequent studies if those analyses are to be pursued. The development of similar networks for the Middle and Late Caddo periods would have utility for constructing hierarchically-nested hypotheses related to the various ways in which the material culture composition of Caddo communities and subcommunities may have changed through time.

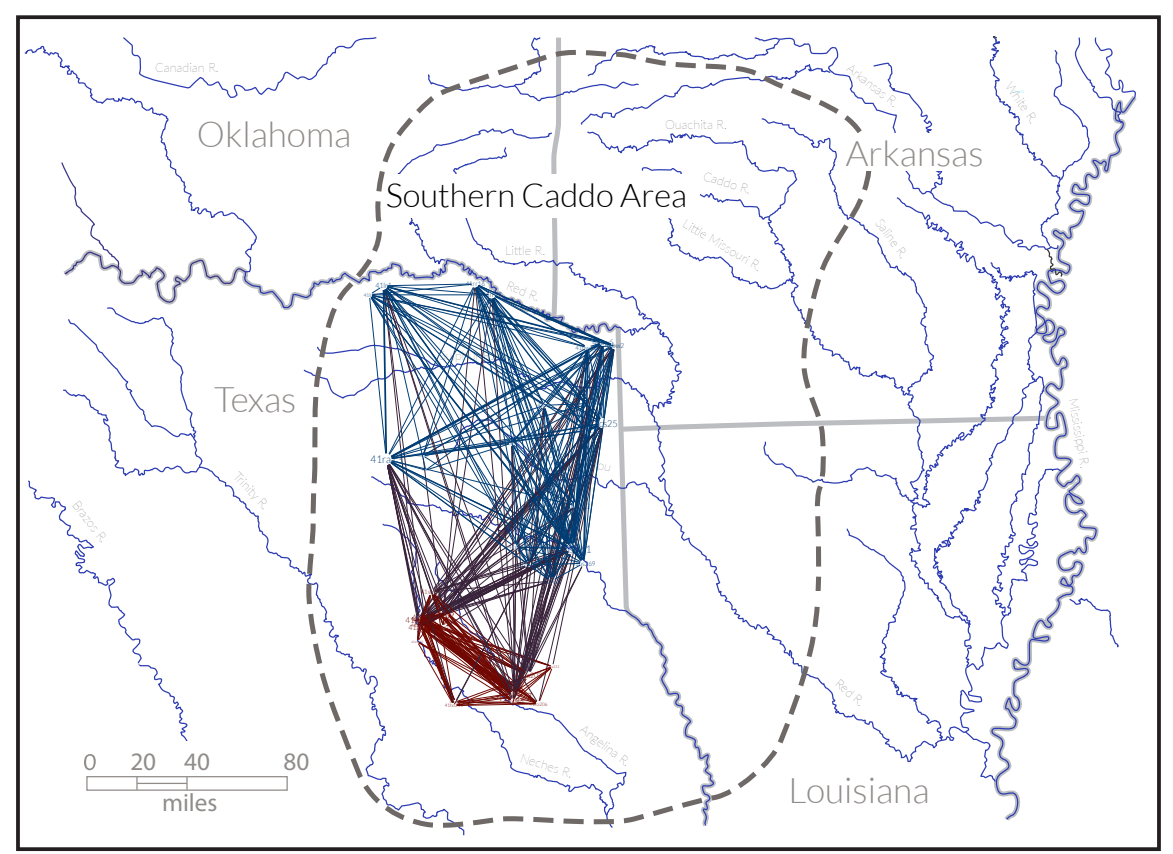

Figure 8: Historic Caddo network generated using ceramic and lithic types, which include Perdiz arrow points (DOI 10.17605/OSF.IO/WD2ZT and Selden Jr. 2021a), illustrating two larger north (blue) and south (red) Caddo communities of practice. The communities were identified using a modularity statistic to identify nodes more densely connected to one another than to the rest of the network (Blondel et al., 2008; Lambiotte et al., 2014).

Temporal differences identified in this study may provide the evidence needed to begin working through ontogenetic explanations that reflect Caddo approaches to the production, maintenance, and discard of Perdiz arrow points (sensu Bird \& O'Connell 2006). There are differences in the approaches that Caddo knap- 
pers used to resolve design-based differences, which are represented at multiple levels: time, raw material, and burial context. As this research programme evolves, it will shift to a landmark-based approach, providing access to more 345 advanced analytical methods, including phenotypic trajectory analysis (Adams \& Collyer, 2007, 2009; Collyer \& Adams, 2013; Collyer et al., 2015), which could be used to investigate potential differential trajectories of phenotypic change through time, and by raw material, burial context, or community of practice. The results of the shape analysis by temporal period are the most pronounced; however, additional research is warranted to assess whether morphological differences existed between the Caddo communities of practice identified in the Historic Caddo network analysis (Selden Jr., 2021a).

Those temporal differences noted among Perdiz point assemblages in the Caddo region may indirectly document the adoption and regional refinement of the point type itself. It is not known whether Perdiz arrow points recovered from central Texas sites reflect similar intraspecific morphological transitions. If such differences do exist, it likely would not be for the same reasons noted in the Caddo area. Additional studies would be required to test this hypothesis. Teasing these apart and assessing the overall influence of each would require directed technological and morphological studies that are beyond the scope of this study. Temporal changes in the type may provide indirect evidence associated with the initiation of extra-regional interaction with Toyah groups beyond the Caddo area. There is evidence of such interactions based on the presence of Caddo ceramics from Toyah sites scattered across central Texas (Kibler, 2012). Vehik (2002) discussed the concept of a southern Plains macroeconomy with cores or nodes consisting of Pueblo and Caddo villages or areas, and Creel (1991) and Vehik (2002) both noted the importance of bison hides and bison products in exchange between the southern Plains and Caddo heartlands. Vehik (2002) further speculated that the Caddo region may be of greater importance than the Pueblo region with regard to trade with Plains groups, noting that Caddo artefacts (mainly pottery) are more common than items from the Southwest, which is also true of the Toyah area (Dockall et al., 2021). 
Perdiz arrow point shapes associated with raw materials used by Caddo knappers to manufacture Perdiz arrow points (chert, quartzite, and silicified wood) were found to differ significantly (Table 6, Figure 6, and supplementary materials Selden Jr. et al., 2021). Unlike ceramic vessels, projectile points represent a single component of a larger technological system (assumed to be the bow and arrow) that archaeologists have been privy to in only the rarest of cases, due primarily to issues of preservation. The degree to which Perdiz arrow points were commodities used for trade and exchange is not understood, and tools like the raw material retouch index posited by Orton (2008) may hold additional value for assessing relative raw material desirability in and among Caddo assemblages. Kuhn (1994) posited that design is an integral component of mobile toolkits, as a means of mitigating risks associated with raw material scarcity, but noted limits related to transporting technological material. Thus, the ideal design is one which provides the greatest potential utility relative to the cost of transport (Kuhn, 1994). Whether design-based differences associated with raw material choice articulated with Caddo cultural or technological differences remains unknown.

It may be that differences in shape based upon raw material choices were related to both Caddo cultural and technological preferences. Certainly, the predominance of chert points incorporated into mortuary contexts by the Late Caddo period is a significant aspect of mortuary behaviour not seen prior to that time. While all raw materials behave similarly in procuring bison or other game, the almost exclusive use of chert in mortuary contexts may be representative of what was considered an appropriate offering during the mortuary event; and may have been related to strengthening extra-regional relationships with other groups. Cherts in general, or cherts from particular source areas, may have been considered more appropriate for the manufacture of Perdiz points that were to be included in mortuary contexts.

That Perdiz points come to figure prominently in the Caddo region by the Late Caddo period suggests that they represent an adopted piece of technology from beyond the Caddo region, given what is presently known of the distribu- 
tion of Perdiz technology from the classic Toyah region of central Texas. The point style may represent Caddo participation in extra regional social and/or economic networks oriented toward bison procurement and hide exchange, potentially using the recently-proposed Toyah Corridor (Carpenter, 2017, 2020). Morphological differences between Caddo Perdiz arrow points from mortuary and non-mortuary contexts may express functional choices or design limitations between points manufactured using different materials. If significant differences in design exist between Perdiz arrow points from Caddo contexts and areas outside the Caddo region, central Texas for instance, one could speculate that functional design-based differences may occur within the type. Perhaps one achieved greater utility in heavily forested regions, and the other in regions that included more open oak and savannah grasslands.

Differences in burial contexts may reflect socially-distinct forms; some utilitarian, and others symbolic (Braun, 1979, 69). However, utilitarian and symbolic characteristics associated with Perdiz arrow points in the Caddo area remain unknown. This analysis demonstrated a significant shape difference in Perdiz arrow points recovered from mortuary and non-mortuary contexts (Figure 7 and Selden Jr. et al. 2021) in which those Perdiz arrow points from outside of mortuary contexts generally express a more oblique shoulder angle, and a broader blade than those recovered from mortuary contexts. As mentioned above, Perdiz arrow points are considered to be one component of a reliable tool (Bleed, 1986), nested in the larger category of curated tools (Binford, 1973). It is possible that the Perdiz arrow points recovered from mortuary contexts articulate with a more symbolic shape, and those recovered outside of mortuary contexts with utilitarian, possibly due to a more expedient or timeconstrained manufacturing process. Thus, the shape of Perdiz arrow points 430 recovered from burials may convey morphological traits that align more closely with locally-diagnostic variants expressive of differential design intent.

While beyond the purview of this study, the function of Perdiz arrow pointswhether utilised as part of a larger projectile-based system or for sawing, cutting, or piercing - may become evident through observing the location and type of 
retouch or use-wear, providing those data necessary to address potential conceptual shifts in archaeological interpretations (Ahler, 1971; Andrefsky Jr., 1997; Harper \& Andrefsky Jr, 2008; Kay, 1996). Christenson (1986) and Hughes (1998) posited that range, accuracy, killing power, and stability were the four major constraints of a functioning missile, and that each could be impacted

440 through retouch. Studies of use-wear and retouch present a unique challenge, since many of the Perdiz arrow points used in this study have been - or are scheduled to be - repatriated, and determinations would have to be conducted through an analysis of previously-collected images.

\section{Conclusion}

This study has documented significant differences in Perdiz arrow point shape across the Middle, Late, and Historic Caddo periods that include changes in arrow point shoulder angles across Caddo history ranging from obtuse in the Middle Caddo period to acute by the Historic Caddo period. The dramatic shift in Perdiz arrow point morphology in the Historic Caddo period correlates temporally with the fluorescence of the fur or peltry trade. It is speculated that some of the shape changes may relate to intentional efforts by the Caddo to manufacture a more lethal and efficient projectile point. Perdiz arrow point shape was also shown to differ by raw material type. The general trend involved both arrow point stem length and symmetry, and formal analyses of bilateral asymmetry are warranted to test those results. Some of the variance can be explained by the geographic occurrence of raw materials. In particular, the mode of occurrence (gravels) for raw materials in northeast Texas and the Caddo region, versus the bedded and large cobble occurrence of cherts in the classic Toyah region of Central Texas. Significant differences in Perdiz arrow point shape were also documented by mortuary contexts, where those recovered from burials generally exhibited narrower blades, well made shoulders/barbs, and more narrow, longer stems.

Results of an exploratory network analysis utilising Historic Caddo ceramic 
and lithic types from multiple northeast Texas sites (including Perdiz points) identified a north-south divide situated between the Neches and Sabine River drainages. This phenomenon was interpreted to represent two distinct Caddo communities of practice. Results of this study illustrate significant differences in the approaches used by Caddo flintknappers to resolve design constraints and weapon-based design intent. These choices are reflected across time, raw material, and burial context (mortuary/non-mortuary). Future detailed studies may provide additional information relevant to regional refinements of the Perdiz type. Many of these findings are directly applicable to the continued development of testable hypotheses regarding regional and locally-based differences related to how Perdiz arrow points were conceived of, and designed, in and

475 among various communities of practice. Such hypotheses can be enlightening with regard to how artisans meaningfully integrated the cultural and material constraints of formal artefact design.

\section{Acknowledgments}

We express our gratitude to the Caddo Nation of Oklahoma and the Anthropology and Archaeology Laboratory at Stephen F. Austin State University for the requisite permissions and access to the NAGPRA items from the Washington Square Mound site and Turner collection. Thanks to Dan McGregor for information on Pisgah Ridge chert, and to Christian S. Hoggard, David K. Thulman, Michael J. O'Brien, and Scott W. Hammerstedt, as well as the edi-

485 tors and reviewers for their comments and constructive criticisms that further improved the manuscript.

Components of the analytical workflow were developed and funded by a Preservation Technology and Training grant (P14AP00138) to RZS from the National Center for Preservation Technology and Training, as well as grants to RZS from the Caddo Nation of Oklahoma, National Forests and Grasslands in Texas (15-PA-11081300-033) and the United States Forest Service (20-PA11081300-074). 


\section{Data Management}

Data and analysis code associated with the various components of this

495 study can be accessed through the supplementary materials (https://akselblaise.github.io/perdiz/), and GitHub repositories for the manuscript or data/code, the latter of which is digitally curated on the Open Science Framework (DOI 10.17605/OSF.IO/DEJ74), where data associated with the contingency table analysis are provided.

\section{References}

Adams, D. C., \& Collyer, M. L. (2007). Analysis of Character Divergence along Environmental Gradients and other Covariates. Evolution, 61, 510-5. URL: https://www.ncbi.nlm.nih.gov/pubmed/ 17348916https://onlinelibrary.wiley.com/doi/full/10.1111/j. 1558-5646.2007.00063.xhttps://onlinelibrary.wiley.com/doi/ pdfdirect/10.1111/j.1558-5646.2007.00063.x?download=true. doi:10.1111/j.1558-5646.2007.00063.x.

Adams, D. C., \& Collyer, M. L. (2009). A General Framework for the Analysis of Phenotypic Trajectories in Evolutionary Studies. Evolution, 63, 1143-54. URL: http://www.ncbi.nlm.nih.gov/pubmed/ 19210539https://onlinelibrary.wiley.com/doi/full/10.1111/j. 1558-5646.2009.00649.xhttps://onlinelibrary.wiley.com/doi/ pdfdirect/10.1111/j.1558-5646.2009.00649.x?download=true. doi:10.1111/j.1558-5646.2009.00649.x.

5 Ahler, S. A. (1971). Projectile Point Form and Function at Rogers Rockshelter, Missouri. Technical Report Research Series No. 8. Missouri Archaeological Society. Columbia.

Ahler, S. A., \& Geib, P. R. (2000). Why Flute? Folsom Point Design and Adaptation. Journal of Archaeological Science, 27, 799-820. doi:10.1006/ jasc.1999.0503. 
Ambrose, S. H. (2006). Howiesons Poort lithic raw material procurement patterns and the evolution of modern human behavior: A response to Minichillo (2006). Journal of Human Evolution, 50, 365369. URL: https://www.sciencedirect.com/science/article/abs/pii/ S0047248405002290?via\%3Dihub. doi:10.1016/j . jhevol.2005.12.006.

Andrefsky Jr., W. (1997). Thoughts on Stone Tool Shape and Inferred Function. Journal of Middle Atlantic Archaeology, 13, 125-145. URL: http://hdl. handle.net/2376/5974.

Banks, L. D. (1990). From Mountain Peaks to Alligator Stomachs: A Review of Lithic Sources in the Trans-Mississippi South, The Southern Plains. Memoir No. 4. Norman: Oklahoma Anthropological Society.

Binford, L. R. (1973). Interassemblage variability - the Mousterian and the 'functional' argument. In C. Renfrew (Ed.), The Explanation of Culture Change: Models in Prehistory (pp. 227-254). Pittsburgh: University of Pittsburgh Press.

Bird, D. W., \& O'Connell, J. F. (2006). Behavioral Ecology and Archaeology. Journal of Archaeological Research, 14, 143-188. doi:10.1007/ s10814-006-9003-6.

Black, S. L. (1986). The Clemente and Herminia Hinojosa Site, 41JW8: A Toyah Horizon Campsite in Southern Texas. Report No. 18, Center for Archaeological Research, The University of Texas at San Antonio. URL: https://scholarworks.sfasu.edu/ita/vol1986/iss1/36/. doi:https:// doi.org/10.21112/ita.1986.1.36.

Bleed, P. (1986). The Optimal Design of Hunting Weapons: Maintainability or Reliability. American Antiquity, 51, 737-747. doi:10.2307/280862.

Bleed, P., \& Meier, M. (1980). An Objective Test of the Effects of Heat Treatment of Flakeable Stone. American Antiquity, 45, 502-507. doi:10.2307/ 279865. 
Blondel, V. D., Guillaume, J.-L., Lambiotte, R., \& Lefebvre, E. (2008). Fast Unfolding of Communities in Large Networks. Journal of Statistical Mechanics: Theory and Experiment, 2008, P10008. URL: <GotoISI>://WOS: 000260529900010https://iopscience.iop.org/article/10.1088/ 1742-5468/2008/10/P10008. doi:10.1088/1742-5468/2008/10/p10008.

Bonhomme, V., Forster, E., Wallace, M., Stillman, E., Charles, M., \& Jones, 555 G. (2017). Identification of inter- and intra-species variation in cereal grains through geometric morphometric analysis, and its resilience under experimental charring. Journal of Archaeological Science, 86, 60-67. doi:10.1016/j . jas.2017.09.010.

Bonhomme, V., Picq, S., Gaucherel, C., \& Claude, J. (2014). Momocs: Outline Analysis Using R. Journal of Statistical Software, 56. doi:10.18637/jss. v056.i13.

Braun, D. P. (1979). Illinois Hopewell Burial Practices and Social Organization: A Reexamination of the Klunk-Gibson Mound Group. In D. S. Brose, \& N. Greber (Eds.), Hopewell Archaeology (pp. 66-79). Kent, Ohio: Kent State University Press.

Brown, K. M. (1976). Fused Volcanic Glass from the Manning Formation. Bulletin of the Texas Archeological Society, 47, 189-207.

Brown, K. M., Potter, D. R., Hall, G. D., \& Black, S. L. (1982). Excavations at 41LK67. A Prehistoric Site in the Choke Canyon Reservoir, South Texas.. Report Center for Archaeological Research, The University of Texas at San Antonio, Choke Canyon Series 7. URL: https://scholarworks.sfasu.edu/ ita/vol1982/iss1/4/. doi:https://doi.org/10.21112/ita.1982.1.4.

Carpenter, S. M. (2017). The Toyah Complex of South and Central Texas: LongRange Mobility and the Emergence of Dual Economies. Plains Anthropologist, 62, 133-156. doi:10.1080/00320447.2016.1258858. 
Carpenter, S. M. (2020). Mesoamerican-Mississippian interaction across the far Southern Plains by long-range Toyah intermediaries. Plains Anthropologist, 65, 325-356. doi:10.1080/00320447.2020.1779910.

Carter, C. E. (1995). Caddo Indians: Where We Come From. Norman, Oklahoma: University of Oklahoma Press.

Christenson, A. L. (1986). Projectile Point Size and Projectile Aerodynamics: An Exploratory Study. Plains Anthropologist, 31, 109-128. doi:https:// doi.org/10.1080/2052546.1986.11909324.

Clark, J. E. (1982). Manufacture of Mesoamerican Prismatic Blades: An Alternative Technique. American Antiquity, 47, 355-376. doi:10.2307/279907.

Cliff, M. B., Green, M., Hunt, S., Shanabrook, D., \& Peter, D. (1996). Excavations in Area C of the Unionville Site (41CS151), White Oak Creek Mitigation Area (WOCMA), Cass County, Texas. Report White Oak Creek Mitigation Area Archeological Technical Series, Report of Investigations No. 4, GeoMarine, Inc., Plano.

Collyer, M. L., \& Adams, D. C. (2013). Phenotypic Trajectory Analysis: Comparison of Shape Change Patterns in Evolution and Ecology. Hystrix, 24, 75-83. URL: http://www.italian-journal-of-mammalogy. it/pdf-77245-13398?filename=Phenotypictrajectory .pdf. doi:doi:10. 4404/hystrix-24.1-6298.

Collyer, M. L., Sekora, D. J., \& Adams, D. C. (2015). A Method for Analysis of Phenotypic Change for Phenotypes Described by High-Dimensional Data. Heredity, 115, 357-65. URL: http://www.ncbi.nlm.nih.gov/pubmed/ 25204302https://www.ncbi.nlm.nih.gov/pmc/articles/PMC4815463/ pdf/hdy201475a.pdf. doi:10.1038/hdy.2014.75.

Creel, D. (1991). Bison Hides in Late Prehistoric Exchange in the Southern Plains. American Antiquity, 56, 40-49. doi:10.2307/280971. 
Densmore, J. A. (2007). A Detailed Analysis of the Variation in Morphology of the Gary Dart Point. Lithic Technology, 32, 7-16. doi:10.1080/01977261. 2007 . 11721040

Dockall, J. E., \& Fields, R. C. (2011). National Register Testing of Three Sites in the Sabine Mine's South Hallsville No. 1 Mine-Rusk Permit, Rusk County, Texas. Technical Report of Investigations No. 162, Prewitt and Associates, Inc., Austin, Texas.

Dockall, J. E., \& Fields, R. C. (2012). Lithic Artifacts. In R. C. Fields, \& E. F. Gadus (Eds.), Archaeology of the Nadaco Caddo: The View from the Pine Tree Mound Site (41HS15) Harrison County, Texas (pp. 553-606). Austin, Texas: Reports of Investigations No. 164. Prewitt and Associates, Inc.

Dockall, J. E., Fields, R. C., Kibler, K. W., Broehm, C. J., Budd, J., Gadus, E. F., \& Gardner, K. M. (2021). Testing and Data Recovery Excavations at the Jayroe Site (41HM51), Hamilton County, Texas (Waco District, CSJ No. 0909-29-030 (Part I)). Technical Report Reports of Investigations No. 187. Prewitt and Associates, Inc., Austin Texas. Archeological Studies Program, Report No. 184. Texas Department of Transportation, Environmental Affairs Division, Archeological Studies Branch, Austin Texas.

Dockall, J. E., Katauskas, S. L., \& Fields, R. C. (2008). National Register Testing of Four Sites in the Sabine Mine's Area M, Harrison County, Texas. Technical Report of Investigations, Number 157. Prewitt and Associates, Inc., Austin, Texas.

Domanski, M., \& Webb, J. A. (2007). A Review of Heat Treatment Research. Lithic Technology, 32, 153-194. URL: https://www.tandfonline. com/doi/abs/10.1080/01977261 .2007.11721052. doi:10.1080/01977261. 2007.11721052 .

Ensor, H. B., Dockall, J. E., \& Winchell, F. (1991). National Register Eligibility 630 testing and Assessment at the Al Soloman I and Al Soloman II Sites, Cypress 
Creek, Harris County, Texas. Technical Report of Investigations No. 12, Archeological Research Laboratory, Texas A\&M University.

Flenniken, J. J. (1985). Stone Tool Reduction Techniques as Cultural Markers. In M. G. Plew, J. C. Woods, \& M. G. Pavesic (Eds.), Stone Tool Analysis: Essays in Honor of Don E. Crabtree (pp. 265-276). Albuquerque: University of New Mexico Press.

Flenniken, J. J., \& Garrison, E. G. (1975). Thermally Altered Novaculite and Stone Tool Manufacturing Techniques. Journal of Field Archaeology, 2, 125131. doi:10.1179/009346975791491303.

Flenniken, J. J., \& Raymond, A. W. (1986). Morphological Projectile Point Typology: Replication Experimentation and Technological Analysis. American Antiquity, 51, 603-614. doi:10.2307/281755.

Foster, W. C. (2008). The Historic Native Peoples of Texas: 1528-1722. Austin: The University of Texas Press.

${ }_{645}$ Gero, J., \& Mazzullo, J. (1984). Analysis of Artifact Shape Using Fourier Series in Closed Form. Journal of Field Archaeology, 11, 315. doi:10.2307/529282.

Girard, J. S. (1995). The Chipped Stone Collection: Technological, Functional, and Typological Analyses. In D. A. Story (Ed.), The Deshazo Site, Nacogdoches County, Texas, Volume 2: Artifacts of Native Manufacture (pp. 33156). Austin: Studies in Archeology 21, Texas Archeological Research Laboratory, The University of Texas.

Gregg, M. L., \& Grybush, R. J. (1976). Thermally Altered Siliceous Stone from Prehistoric Contexts: Intentional versus Unintentional Alteration. American Antiquity, 41, 189-192. doi:10.2307/279170.

${ }_{655}$ Haberman, S. J. (1973). The Analysis of Residuals in Cross-Classified Tables. Biometrics, 29. doi:https://doi.org/10.2307/2529686. 
Harper, C., \& Andrefsky Jr, W. (2008). Exploring the Dart and Arrow Dilemma: Retouch Indices as Functional Determinants. In W. Andrefsky Jr (Ed.), Lithic Technology (pp. 175-191). New York: Cambridge University Press.

Hoggard, C. S., McNabb, J., \& Cole, J. N. (2019). The Application of Elliptic Fourier Analysis in Understanding Biface Shape and Symmetry Through the British Acheulean. Journal of Paleolithic Archaeology, 2, 115-133. doi:10. 1007/s41982-019-00024-6.

Hughes, S. S. (1998). Getting to the Point: Evolutionary Change in Prehistoric Weaponry. Journal of Archaeological Method and Theory, 5, 345-408. doi:https://doi.org/10.1007/BF02428421.

Ioviţă, R. (2009). Ontogenetic Scaling and Lithic Systematics: Method and Application. Journal of Archaeological Science, 36, 1447-1457. doi:10.1016/ j.jas.2009.02.008.

670

Ioviţă, R. (2010). Comparing Stone Tool Resharpening Trajectories with the Aid of Elliptical Fourier Analysis. In S. J. Lycett, \& P. Chauhan (Eds.), New Perspectives on Old Stones: Analytical Approaches to Paleolithic Technologies (pp. 235-253). New York: Springer-Verlag New York. doi:10.1007/978-1-4419-6861-6_10.

Ioviţă, R. (2011). Shape variation in Aterian tanged tools and the origins of projectile technology: A morphometric perspective on stone tool function. PLoS One, 6, e29029. URL: http://www.ncbi.nlm.nih.gov/pubmed/22216161. doi:10.1371/journal pone.0029029.

Ioviţă, R., \& McPherron, S. P. (2011). The Handaxe Reloaded: A Morphometric 680 Reassessment of Acheulian and Middle Paleolithic Handaxes. Journal of Human Evolution, 61, 61-74. URL: http://www.ncbi.nlm.nih.gov/pubmed/ 21496877. doi:10.1016/j.jhevol.2011.02.007.

Ioviţă, R., Tuvi-Arad, I., Moncel, M.-H., Desprie’e, J., Voinchet, P., \& Bahain, J.-J. (2017). High Handaxe Symmetry at the Beginning of the Euro- 
pean Acheulian: The Data from La Noira (France) in Context. PLoS One, 12, e0177063. URL: https://www.ncbi.nlm.nih.gov/pubmed/28520745. doi:10.1371/journal pone. 0177063.

Ivanovaitè, L., Serwatka, K., Hoggard, C. S., Sauer, F., \& Riede, F. (2019). All these Fantastic Cultures? Research History and Regionalization in the Late Palaeolithic Tanged Point Cultures of Eastern Europe. European Journal of Archaeology, 23, 162-185. doi:10.1017/eaa.2019.59.

Johnson, L. (1994). The Life and Times of Toyah-Culture Folk: The Buckhollow Encampment Site 41KM16, Kimble County, Texas. Report Texas Department of Transportation and Office of the State Archeologist Report 38. Austin, Texas.

Kay, M. (1996). Microwear Analysis of Some Clovis and Experimental Chipped Stone Tools. In G. Odell (Ed.), Stone Tools: Theorectical Insights into Human Prehistory (pp. 315-344). New York: Plenum Press.

Kibler, K. W. (2012). The Role of Exotic Materials in Toyah Assemblages in a Late Prehistoric Economic and Social System. In N. A. Kenmotsu, \& D. K. Boyd (Eds.), The Toyah Phase of Central Texas: Late Prehistoric Economic and Social Processes (pp. 76-89). College Station, Texas: Texas A\&M University Press.

Kuhn, S. L. (1994). A Formal Approach to the Design and Assembly of Mobile Toolkits. American Antiquity, 59, 426-442. doi:https://doi.org/10.2307/ 282456.

Lambiotte, R., Delvenne, J.-C., \& Barahona, M. (2014). Random Walks, Markov Processes and the Multiscale Modular Organization of Complex Networks. IEEE Transactions on Network Science and Engineering, 1, 76-90. URL: https://ieeexplore.ieee.org/document/7010026/. doi:10. $1109 /$ tnse. 2015.2391998. 
LaVere, D. (1998). The Indians of Texas. College Station: Texas A\&M University Press.

Malone, J. M. (1972). Archaeological Reconnaissance at Proposed Mineola Reservoir. Report Archeological Survey Report No. 10, Texas Historical Survey Committee.

McGregor, D. (1993). Pisgah Ridge Chert Distributions: Evidence for Changing Territorial Size in North Central Texas. Bulletin of the Texas Archeological Society, 64, 247-267.

720

Mercieca, A., \& Hiscock, P. (2007). Experimental insights into alternative strategies of lithic heat treatment. Journal of Archaeological Science, 35, 2634-2639. doi:10.1016/j.jas. 2008.04.021.

Newcomer, M. H. (1971). Some Quantitative Experiments in Hand-Axe Manufacture. World Archaeology, 3, 85-95. doi:10.1080/00438243.1971.9979493.

Orton, J. (2008). A useful measure of the desirability of different raw materials for retouch within and between assemblages: The raw material retouch index (RMRI). Journal of Archaeological Science, 35, 1090-1094. doi:10.1016/j . jas.2007.08.002.

Perttula, T. K. (1984). Patterns of Prehistoric Lithic Raw Material Utilization in the Caddoan Area: Western Gulf Coastal Plain. In B. M. May, \& E. E. Butler (Eds.), Prehistoric Chert Exploitation: Studies from the Mid-Continent (pp. pp. 129-148). Occasional Paper 2. Center for Archaeological Investigations, Southern Illinois University, Carbondale.

Prewitt, E. R. (1995). Distributions of Typed Projectile Points in Texas. Bulletin of the Texas Archeological Society, 66, 83-174.

Ricklis, R. A. (1994). Toyah Components: Evidence for Occupation in the Project Area during the Latter Part of the Late Prehistoric Period. In R. A. Ricklis, \& M. B. Collins (Eds.), Archaic and Late Prehistoric Human Ecology in the Middle Onion Creek Valley, Hays County, Texas (pp. 207-316). 
Austin, Texas: Studies in Archeology 19. Vol. 1, Texas Archeological Research Laboratory, University of Texas.

Saragusti, I., Karasik, A., Sharon, I., \& Smilansky, U. (2005). Quantitative analysis of shape attributes based on contours and section profiles in artifact analysis. Journal of Archaeological Science, 32, 841-853. doi:10.1016/j. $745 \quad j a s .2005 .01 .002$.

Selden Jr., R. Z. (2018a). A Preliminary Study of Smithport Plain Bottle Morphology in the Southern Caddo Area. Bulletin of the Texas Archeological Society, 89, 63-89. URL: https://scholarworks.sfasu.edu/crhr/283/.

Selden Jr., R. Z. (2018b). Ceramic Morphological Organisation in the Southern Caddo Area: Quiddity of Shape for Hickory Engraved Bottles. Journal of Archaeological Science: Reports, 21, 884-896. doi:10.1016/j.jasrep. 2018. 08.045 .

Selden Jr., R. Z. (2019). Ceramic Morphological Organisation in the Southern Caddo Area: The Clarence H. Webb Collections. Journal of Cultural Heritage, 35, 41-55. URL: https://www.sciencedirect. com/science/article/abs/pii/S1296207418301912?via\%3Dihub. doi:10. 1016/j.culher.2018.07.002.

Selden Jr., R. Z. (2021a). An Exploratory Network Analysis of the Historic Caddo Period in Northeast Texas. In D. P. McKinnon, T. K. Perttula, \& 760 J. S. Girard (Eds.), Ancestral Caddo Ceramic Traditions (pp. 240-257). Baton Rouge: LSU Press.

Selden Jr., R. Z. (2021b). Louisiana Limitrophe: An Iterative Morphological Exegesis of Caddo Bottle and Biface Production. In D. P. McKinnon, J. S. Girard, \& T. K. Perttula (Eds.), Ancestral Caddo Ceramic Traditions (pp. 258-276). Baton Rouge: LSU Press.

Selden Jr., R. Z., Dockall, J. E., Bousman, C. B., \& Perttula, T. K. (2021). Supplementary materials for paper: Shape as a function of time + raw material + 
burial context? A preliminary analysis of Perdiz arrow points in the southern Caddo area. Open Science Framework, . doi:10.17605/OSF. IO/DEJ74.

Selden Jr., R. Z., Dockall, J. E., \& Dubied, M. (2020). A quantitative assessment of intraspecific morphological variation in Gahagan bifaces from the southern Caddo area and central Texas. Southeastern Archaeology, 39, 125-145. doi:10.1080/0734578x.2020.1744416.

Selden Jr., R. Z., Dockall, J. E., \& Shafer, H. J. (2018). Lithic Morphological Organisation: Gahagan Bifaces from the Southern Caddo Area. Digital Applications in Archaeology and Cultural Heritage, 10, e00080. doi:10.1016/j . daach.2018.e00080.

Serwatka, K. (2015). Shape Variation of Middle Palaeolithic Bifacial Tools from Southern Poland: A Geometric Morphometric Approach to Keilmessergruppen Handaxes and Backed Knives. Lithics, 35, 18-32. URL: http:// journal.lithics.org/index.php/lithics/article/viewFile/371/353.

Smith, F. T. (1995). The Caddo Indians: Tribes at the Convergence of Empires, 1542 - 1854. College Station: Texas A\&M University Press.

Stoeser, D. B., Shock, N., Green, G. N., Dumonceaux, G. M., \& Heran, W. D. 785 (2005). Geologic Map Database of Texas, Version 1.1. Report U.S. Geological Survey Data Series, DS 170, Denver, Colorado.

Stoutamire, S., \& McBride, M. (2020). A Rocks Long Journey: Unraveling Bedrock Sources to Deposition Areas for the Uvalde Gravels. Bulletin of the Texas Archeological Society, 91, 187-203.

790

Suhm, D. A., \& Jelks, E. B. (1962). Handbook of Texas Archeology: Type Descriptions. Austin: Special Publication No. 1. Texas Archeological Society and Bulletin No. 4, Texas Memorial Museum.

Suhm, D. A., Krieger, A. D., \& Jelks, E. B. (1954). An Introductory Handbook of Texas Archeology. Bulletin of the Texas Archeological Society, 25, 1-562. 
Team, R. C. D. (2021). R: A Language and Environment for Statistical Computing. Electronic resource,. Vienna, Austria: R Foundation for Statistical Computing. URL: http://www.R-project.org.

Teltser, P. A. (1991). Generalized Core Technology and Tool Use: A Mississippian Example. Journal of Field Archaeology, 18, 363-375. doi:10.1179/ 009346991791548681.

Vehik, S. C. (2002). Conflict, Trade, and Political Development on the Southern Plains. American Antiquity, 67, 37-64. doi:10.2307/2694876.

Yaroshevich, A., Kaufman, D., Nuzhnyy, D., Bar-Yosef, O., \& Weinstein-Evron, M. (2010). Design and performance of microlith implemented projectiles during the Middle and the Late Epipaleolithic of the Levant: Experimental and archaeological evidence. Journal of Archaeological Science, 37, 368-388. doi:10.1016/j.jas . 2009.09. 050. 